\title{
Use of Molecular Markers to Identify Certain Stem Rust Resistance Genes in Thirteen Bread Wheat Cultivars Registered in Egypt M.M. El-Shamy" and A.F. Omar**
}

Wheat Dis. Res. Dept., Plant Pathol. Res. Inst., ARC, Giza, Egypt. ** Botany Dept., Plant Pathol. \& Biotechnol. Lab., Fac. Agric., Kafr El-Sheikh Univ.

\begin{abstract}
Wheat stem rust caused by Puccinia graminis f.sp. tritici $(P g t)$ is one of the most destructive diseases of wheat all over the world. In Egypt, in-spite of the absence of the new stem rust pathotype TTKS (syn. Ug99) and its variants TTKSK and TTKST, the disease takes place as a serious situation in the last few years with high disease severities on most of the common wheat cultivars during 2012-2014 growing seasons. A modified North American Pgt differential set representing the resistance genes $\operatorname{Sr} 5,21,9 \mathrm{e}, 7 \mathrm{~b}, 11,6$, 8a, 9g, 36, 9b, 30, 17, 9a, 9d, 10, Tmp, 24, 31, 38 and $\mathrm{McN}$, respectively, as well as 10 supplemental $\mathrm{Sr}$ genes were evaluated in natural field infection. Adult resistance plants were detected on $\mathrm{Sr}$ genes $\operatorname{Sr}$ 5, Sr 9g, Sr 11, Sr 13, Sr 14, Sr 21, Sr 24, Sr 28 and $\operatorname{Sr} 38$. Four specific markers were selected to detect the presence of the resistant stem rust monogenic lines including $\mathrm{Sr} 13, \mathrm{Sr} 25, \mathrm{Sr} 26$ and $S r 31$ in thirteen Egyptian bread wheat cultivars. These markers were XBE403950EST, PSY-DI, Sr26\#43 STS and IAG95-STS, respectively. Stem rust resistance gene $S r 26$ was absent in all the tested cultivars, whereas $\operatorname{Sr} 13, \operatorname{Sr} 25$ and $S r 31$ were presented at various frequencies. The highest frequency was observed for $\operatorname{Sr} 13$ (100\%), followed by $\operatorname{Sr} 25(84.61 \%)$ and $S r 31(46.15 \%)$. These results revealed that DNA marker for $S r 26$ is needed in the Egyptian cultivars and more effective genes must be identified and incorporate in adopted germplasms to face such disease.
\end{abstract}

Keywords: DNA markers, molecular marker, Puccinia graminis f.sp. tritici, $\mathrm{Sr}$ genes, Ug99 and wheat.

Wheat (Triticum aestivum L.), is the largest cultivated crop in both cultivated areas and total production in the world. Stem rust caused by Puccinia graminis Pers. f.sp. tritici Eriks. and E. Henn., is one of the major diseases of wheat throughout the world. New Pgt strain Ug99 was detected by Pretorius et al. (2000) and was designated by Wanyera et al. (2006) as TTKS pathotype. It showed a virulence to Sr31 and its variants, TTKST and TTTSK which were detected in Kenya in 2006 and 2007 with virulence to genes Sr24 and Sr36, respectively, (Jin et al., 2008). They pose a serious threat to bread wheat (Triticum aestivum L.). Controlling the disease through usage of chemicals besides being costly to the farmer is also harmful to the environment. Utilization of resistant cultivars is the most economical and environmental-friendly approach to control the diseases, enabling reductions in fungicide use. A diversified and effective resistant gene resource must be the basis 
of breeding wheat cultivars with stem rust resistance. To date, 55 stem rust resistance genes have been identified and formally catalogued on different wheat chromosomes (McIntosh et al., 2011 and Ghazvini et al., 2013). Incorporation of the resistance genes is eco-friendly system which does not place any cost burden on the growers (Ejaz et al., 2012). The durability of effective resistance genes can be enhanced by deploying them as multiple genes in cultivars. $S r 25$ and $S r 26$ genes are among a few major genes effective against TTKS lineage that includes TTKST and TTTSK races (Singh et al., 2006 and Jin et al., 2007). Nowadays, various molecular markers have been widely used in plant genetic mapping and marker-assisted selection (MAS), such as random amplified polymorphic DNA (RAPD), amplified fragment length polymorphism (AFLP), restriction fragment length polymorphism (RFLP), sequence tagged site (STS), simple sequence repeat(SSR), inter-simple sequence repeat (ISSR). Currently, microsatellites (simple sequence repeats, SSR) are the preferred type of molecular marker for marker-assisted selection (MAS) in wheat breeding.

In this study our objective was to check whether the stem rust resistance genes, Sr13, Sr25, Sr 26 and Sr31 are presented in thirteen registered Egyptian bread wheat cultivars recently grown and to determine their frequencies using SSR technique.

\section{Materials and Methods}

\section{Adult plant resistance to wheat stem rust:}

Twenty modified North American Pgt differential set representing the resistance genes $\operatorname{Sr} 5,21,9 \mathrm{e}, 7 \mathrm{~b}, 11,6,8 \mathrm{a}, 9 \mathrm{~g}, 36,9 \mathrm{~b}, 30,17,9 \mathrm{a}, 9 \mathrm{~d}, 10, \mathrm{Tmp}, 24,31,38$ and McN, respectively, (Pretorius et al., 2000) as well as 10 supplemental stem rust monogenic lines i.e. Sr 7a, Sr 8b, Sr 13, Sr 14, Sr 15, Sr 22, Sr 25, Sr 26. Sr 27 and Sr 28 were used in this study (Table 3). These lines were obtained from Wheat Dis. Res. Dept., Plant Dis. Res. Inst., ARC, Giza. These lines were evaluated to natural infection of stem rust disease in the farm of Gemmeiza Res. St. in 2013/2014 growing season. $S r$ lines were sown in rows $5 \mathrm{~m}$ long, $50 \mathrm{~cm}$ apart between the rows and $5 \mathrm{~cm}$ within plants. All agricultural practices were performed as recommended. Disease severity was recorded at adult stage on the basis to the modified Cobb scale 0 to $100 \%$ (Peterson et al., 1948).

\section{DNA extraction:}

Thirteen Egyptian bread wheat cultivars adapted in Egypt, obtained from the National Wheat Program, Crops Res. Inst., ARC, Giza, as well as four stem rust monogenic lines, i.e. Sr13, Sr25, Sr26 and Sr31, were listed in Table (1) according to their responses at seedling and adult stages to stem rust seedlings of the previously mentioned bread wheat cultivars and monogenic lines were used at 15 days old for genomic DNA extraction (PCR analysis). Total DNA of each wheat cultivar and isogenic line was extracted from $200 \mathrm{mg}$ leaf tissue which digested in liquid nitrogen with a mortar and pestle using Invisorb ${ }^{\circledR}$ Spin Plant Mini Kit (STRATEC Molecular, Germany) according to manufacturer's instructions. 
Table 1. Bread wheat cultivars and stem rust monogenic lines (Sr's) used in this study

\begin{tabular}{|c|c|}
\hline Cultivar/Sr gene & Pedigree \\
\hline Gemmeiza-7 & $\begin{array}{l}\text { CMH74A.360 / 5x // Seri82 /3/ Agent CGM4611-2GM-3GM- } \\
\text { 1GM-0GM. }\end{array}$ \\
\hline Gemmeiza-10 & Maya 74"S"/ On // 1160-174/3/ Bb /4/ Chal "S"/5/Ctow. \\
\hline Gemmeiza-11 & $\begin{array}{l}\text { BUC"S"/ Kvz"S"// 7c/ Seri 82 /3/Giza 168/ Sakha } 61 \\
\text { GM7892-2GM-1GM-0 GM. }\end{array}$ \\
\hline Gemmeiza-12 & $\begin{array}{l}\text { OTS /3/ SARA/ THB// Vee-CMss97Y0027S-5Y-010M- } \\
\text { 010Y-010M-2Y-1M-0Y-06M-06M-0GM. }\end{array}$ \\
\hline Sids-12 & $\begin{array}{l}\text { BUC // 7c / Ald /5/ Maya } 74 \text { / On / 1160.147/3 / BB/ G11 /4/ } \\
\text { Chat "S" /6/ Maya / vu1 // Cmh 74A.630/4* sx, SD7096- 4SD- } \\
\text { 1SD-0SD. }\end{array}$ \\
\hline Sids-13 & $\begin{array}{l}\text { ALmaz 19= Kauz "S" // Tsi /snb "S" ICW 94-0375- 4AP- } \\
\text { 2AP-030AP-) APS- 2AP- 0APS- 050AP- 0AP- 0SD. }\end{array}$ \\
\hline Sids-14 & $\begin{array}{l}\text { SW8488*2 / KUKUNA- CGSS01Y00081T- 099M-099Y- } \\
\text { 099M-099B-9Y-0B-0SD. }\end{array}$ \\
\hline Giza-168 & MIL /BUC // Seri CM93046-8M-0Y-0M-2Y-0M. \\
\hline Giza-171 & Gemmeiza-9 / Sakha-93. \\
\hline Misr-1 & $\begin{array}{l}\text { Oasis /skauz // 4* BCN/3/2* Pastor CMss 00Y01881T-050M- } \\
\text { 030Y-030M-030WGY-33M- 0Y-0S. }\end{array}$ \\
\hline Misr-2 & $\begin{array}{l}\text { SKAUZ / BAV 92. CMss } 96 \text { M03611S- 1M- 0105Y-010M- } \\
\text { 010SY- 8M- 0Y-0S. }\end{array}$ \\
\hline Sahka-93 & Sakha 92TR81032 S8871-1S-2S-1S-0S. \\
\hline Gemmeiza-9 & $\begin{array}{l}\text { Ald"S"/ Huac"S" // CMH 74A.630/ 5x CGM 4583-5GM- } \\
\text { 1GM-0GM. }\end{array}$ \\
\hline Sr13 & Prelude $^{*} 4$ /2/ marquis ${ }^{*} 6 /$ Khapstein. \\
\hline $\operatorname{Sr} 25$ & Agatha(CI 14048)/9*LMPG-6 DK16 \\
\hline Sr26 & Eagle $S r 26$ \\
\hline $\mathrm{Sr} 31$ & Sr31(Benno) / 6"LMPG-6 DK42. \\
\hline
\end{tabular}

\section{Condition and amplification of PCR:}

Amplification of $\mathrm{Sr}$ regions were conducted in an automated thermal cycler $\left(\mathrm{C} 1000^{\mathrm{TM}}\right.$ Thermal Cycler, Bio-RAD) using the primers and conditions listed in Table (2) with one pre-denaturation cycle at $94^{\circ} \mathrm{C}$ for $3 \mathrm{~min}$. Each PCR mixture was $25 \mu \mathrm{l}$ as follow, $1 \mu \mathrm{l}$ of $25 \mathrm{ng}$ nucleic acid, $1 \mu \mathrm{l}$ of each primer $(10 \mathrm{pmol})$, forward and reverse, $12.5 \mu 1$ of GoTag® Colorless Master Mix (Promega Corporation, USA) and $9.5 \mu 1$ of Nuclease free water (Promega). $15 \mu 1$ of all PCR products were analyzed by electrophoresis through a $1.5 \%$ agarose gel, stained with ethidium bromide, and DNA bands were visualized using a UV trans- illuminator and photographed. 
Table 2. Primers and PCR conditions for markers associated with Sr13, Sr25, Sr26 and Sr31 monogenic lines

\begin{tabular}{|c|c|c|c|}
\hline Primer name & $\begin{array}{c}\text { Monogenic } \\
\text { line }\end{array}$ & Primer sequence & PCR conditions \\
\hline $\begin{array}{l}\text { XBE403950 } \\
\text { EST (Simons } \\
\text { et al., 2011) }\end{array}$ & $\operatorname{Sr} 13$ & $\begin{array}{l}\text { F- 5`-GGAACATGTTGACGCTGTTG-3` } \\
\text { R- 5`-AACACTGTTCCCGAAGTTGG-3` }\end{array}$ & $\begin{array}{l}\text { Amplification step: ( } 35 \\
\text { cycles ): } 94^{\circ} \mathrm{C}, 20 \mathrm{sec} . \\
53^{\circ} \mathrm{C}, 20 \mathrm{sec}, 72^{\circ} \mathrm{C}, 30 \\
\text { sec \& final extension at } \\
72^{\circ} \mathrm{C}, 7 \text { min. }\end{array}$ \\
\hline $\begin{array}{l}\text { PSY-DI } \\
\text { (Zhang \& } \\
\text { Dubcovsky, } \\
2008 \text { ) }\end{array}$ & $\operatorname{Sr} 25$ & $\begin{array}{l}\text { F- 5'-TTGCAGTGCAATGGTTTTCCA-3' } \\
\text { R- 5'GACTCCTTTGACGATGTCTTC-3' }\end{array}$ & $\begin{array}{l}\text { Amplification step:( } 35 \\
\text { cycles }): 94^{\circ} \mathrm{C}, 20 \\
\text { ec. }, 53^{\circ} \mathrm{C}, 20 \mathrm{sec}, 72^{\circ} \mathrm{C}, 30 \\
\text { sec \& final extension at } \\
72^{\circ} \mathrm{C}, 7 \mathrm{~min}\end{array}$ \\
\hline $\begin{array}{l}\text { Sr26\#43 STS } \\
\text { (Mago et al., } \\
2005 \text { ) }\end{array}$ & $\operatorname{Sr} 26$ & $\begin{array}{l}\text { F- 5'AATCGTCCACATTGGCTTCT-3' } \\
\text { R- 5'CGCAACAAAATCATGCACTA-3' }\end{array}$ & $\begin{array}{l}\text { Amplification } \\
\text { step:(35cycles): } \\
94^{\circ} \mathrm{C}, 60 \mathrm{sec} ., 52^{\circ} \mathrm{C}, 60 \mathrm{sec}, 7 \\
2^{\circ} \mathrm{C}, 120 \mathrm{sec}, \text { and final } \\
\text { extension at } 72^{\circ} \mathrm{C}, 10 \mathrm{~min}\end{array}$ \\
\hline $\begin{array}{l}\text { IAG95-STS } \\
\text { (Mago et al., } \\
\text { 2002) }\end{array}$ & $\operatorname{Sr} 31$ & $\begin{array}{l}\text { F-5'-CTCTGTGGATAGTTACTTGATCGA-3' } \\
\text { R-5'-CTAGAACATGCATGGCTGTTACA-'3 }\end{array}$ & $\begin{array}{l}\text { Amplification step: } \\
\text { (35cycles): } \\
4^{\circ} \mathrm{C}, 20 \mathrm{sec} ., 55^{\circ} \mathrm{C}, 20 \mathrm{sec}, 72 \\
{ }^{\circ} \mathrm{C}, 30 \mathrm{sec} \& \text { final } \\
\text { extension at } 72^{\circ} \mathrm{C}, 7 \mathrm{~min}\end{array}$ \\
\hline
\end{tabular}

\section{Results and Discussion}

Data in Table (3) revealed the different levels responses of $30 \mathrm{Sr}$ genes to stem rust natural infection at Gemmeiza Res. Station field in 2013/ 2014 growing season. High infection disease severity was recorded on $\mathrm{Sr}$ genes $\mathrm{Sr}$ 6, $\mathrm{Sr} 7 \mathrm{a}, \mathrm{Sr}$ 9b, $\mathrm{Sr}$ 9d, $\mathrm{Sr}$ 17 and $\operatorname{Sr} \mathrm{McN}$ (40-50-S), moderate disease severity $\operatorname{Sr} 8 \mathrm{a}, \operatorname{Sr} 10, \operatorname{Sr} 15, \operatorname{Sr} 25, \operatorname{Sr} 30$ and $\operatorname{Sr}$ Tmp (10 -30S). Low disease severity was observed with $\operatorname{Sr} 7 \mathrm{~b}, \mathrm{Sr} 8 \mathrm{~b}, \mathrm{Sr} 9 \mathrm{a}$, $S r 9$ e, $S r 27$ and $S r 31$. However, complete resistance responses were recorded on $S r$ 5, Sr 9g, Sr 11, Sr 13, Sr 14, Sr 21, Sr 22, Sr 24, Sr 26, Sr 28, Sr 36 and Sr 38.

Similar results were obtained by Wanyera et al.(2006) and Jin et al. (2007) Who summarized the results of adult plant infection responses and seedling infection types for monogenic lines of designated $\mathrm{Sr}$ genes challenged with race TTKS. High infection types at the seedling stage and susceptible infection responses in adult plants were observed on monogenic lines carrying $\operatorname{Sr} 5,6,7 \mathrm{a}, 7 \mathrm{~b}, 8 \mathrm{a}, 8 \mathrm{~b}, 9 \mathrm{a}, 9 \mathrm{~b}, 9 \mathrm{~d}$, $9 \mathrm{~g}, 10,11,12,15,16,17,18,19,20,23,30,31,34,38$ and Wld-1. Monogenic lines of resistance genes $S_{r} s$ 13, 22, 24, 25, 26, 27, 28, 32, 33, 35, 36, 37, 39, 40, 44, Tmp and Tt-3 were effective against TTKS at seedling and adult plant stages.

Microsatellite PCR:

Four selected microsatellite markers were used to detect whether they reveal polymorphic bands between the stem rust genes, $\operatorname{Sr} 13, \operatorname{Sr} 25, \operatorname{Sr} 26$ and $\operatorname{Sr} 31$, and thirteen bread wheat cultivars commonly grown in Egypt using simple sequence repeat (SSR) technique. 
Table 3. Response of thirty stem rust monogenic lines to natural infection of stem rust in 2013/2014 growing season

\begin{tabular}{|c|c|c|c|}
\hline$S r$ genes & Disease severity & $S r$ genes & Disease severity \\
\hline$S r 5$ & 0 & $S r 15$ & $10-\mathrm{S}$ \\
\hline $\operatorname{Sr} 6$ & $40-S$ & Sr 17 & $40-\mathrm{S}$ \\
\hline$S r 7 a$ & $50-S$ & Sr 21 & 0 \\
\hline $\mathrm{Sr} 7 \mathrm{~b}$ & $5-S$ & Sr 22 & 0 \\
\hline $\operatorname{Sr} 8 \mathrm{a}$ & $20-S$ & Sr 24 & 0 \\
\hline $\mathrm{Sr} 8 \mathrm{~b}$ & $5-S$ & Sr 25 & $20-S$ \\
\hline $\operatorname{Sr} 9 \mathrm{a}$ & $5-S$ & Sr 26 & 0 \\
\hline $\operatorname{Sr} 9 \mathrm{~b}$ & $50-S$ & Sr 27 & Tr-S \\
\hline $\operatorname{Sr} 9 \mathrm{~d}$ & $50-S$ & Sr 28 & 0 \\
\hline $\operatorname{Sr} 9 \mathrm{e}$ & Tr-S & Sr 30 & $20-S$ \\
\hline $\operatorname{Sr} 9 \mathrm{~g}$ & 0 & Sr 31 & $5-S$ \\
\hline Sr 10 & $10-S$ & Sr 36 & 0 \\
\hline Sr 11 & 0 & Sr 38 & 0 \\
\hline Sr 13 & 0 & Sr Tmp & $30-S$ \\
\hline Sr 14 & 0 & $\mathrm{Sr} \mathrm{McN}$ & $40-\mathrm{S}$ \\
\hline
\end{tabular}

Sr13:

Microsatalite dominant marker, XBE403950 EST amplified a DNA fragment of 700 bp known to be associated with $\operatorname{Sr} 13$ indicating the presence of $\operatorname{Sr} 13$ in all the tested bread wheat cultivars (Fig.1). Simons et al. (2011) reported that the XBE403950 EST amplified a DNA fragment of 691-723 bp for $\mathrm{Sr} 13$. The stem rust resistance gene $\mathrm{Sr} 13$ presents in several Triticum turgidum sp. durum cultivars. Its main sources are the Ethiopian land race ST464 and the T. turgidum sp. dicoccon L. (emmer wheat) germplasm Khapli (Knott, 1962). Klindworth et al. (2007) stated that currently, $\operatorname{Sr} 13$ gene is the only one effective against the TTKS complex within the US durum wheat adapted cultivars. It is present in some common durum cultivars like Kofa, Kronos, Langdon, Medora and Sceptre. This gene confers a moderate type of resistance, so it is recommended to deploy this gene pyramided with other resistance genes, which will also extend the durability of the individual genes.

Sr25:

The dominant marker PSY-D1 was used to detect stem rust resistance gene $S r 25$. This marker amplified a product of 175 bp DNA fragment (Fig. 2). Data revealed the presence of $S r 25$ in all the wheat cultivar except Misr-1 and Misr-2 bread wheat cultivars (Fig.2). Sr25 and the linked leaf rust resistance gene Lr19 were translocated onto the long arm of wheat chromosomes 7D (Friebe et al., 1994). Genes $\operatorname{Sr} 25$ and $S r 26$ transferred into wheat from Thinopyrum ponticum are effective against the Sr31-virulent race Ug99 (TTKSK) and its Sr24-virulent derivative (TTKST). So, it was then backcrossed into Australian wheat cultivars and has been used in the CIMMYT wheat breeding program (Bariana et al., 2007). 


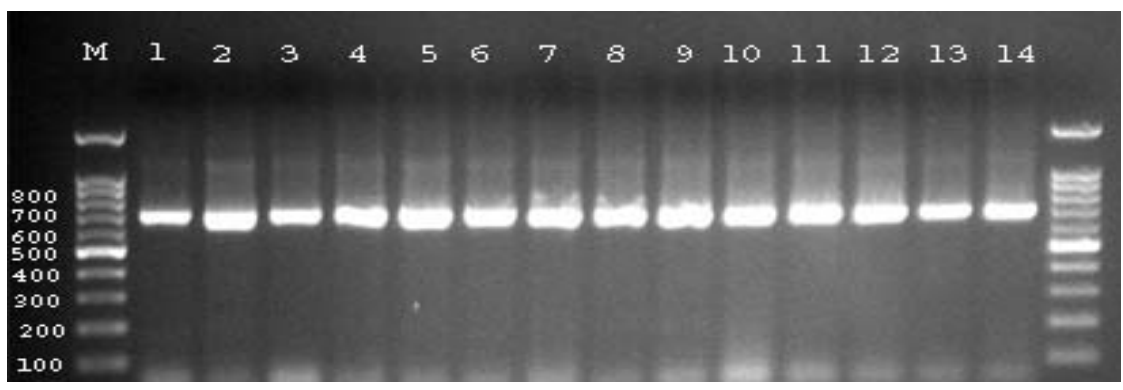

Fig.1. The fragment profile of the XBE403950 with one band labeled as $700 \mathrm{bp}$ indicates the presence of $S r 13$ in all of the thirteen bread wheat cultivars. M: 1000bp DNA ladder RTU (Gene Direx), 1: Sr13 gene; 2: Gemmeiza-7, 3: Gemmeiza-10, 4: Gemmeiza-11, 5: Gemmeiza-12, 6: sids-12, 7: Sids-13, 8: Sids-14, 9: Giza-168, 10: Giza-171, 11: Misr-1, 12: Misr-2, 13: Sahka93, 14: Gemmeiza-9.

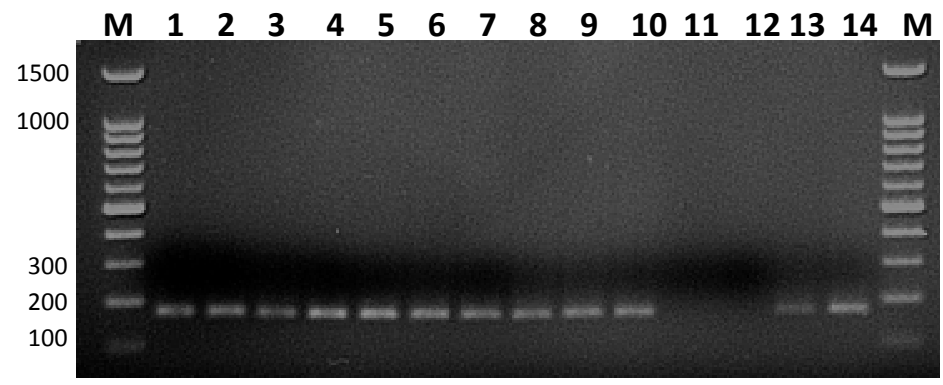

Fig.2. The fragment profile of the PSY-D1 with one band labeled as $175 \mathrm{bp}$ indicates the presence of $S r 25$ in 11 out of the thirteen bread wheat cultivars. M: 1000bp DNA ladder RTU (Gene Direx), 1: Sr25; 2: Gemmeiza-7, 3: Gemmeiza-10, 4: Gemmeiza-11, 5: Gemmeiza-12, 6: sids-12, 7: Sids-13, 8: Sids-14, 9: Giza-168, 10: Giza-171, 11: Misr-1, 12: Misr-2, 13: Sahka93, 14: Gemmeiza-9.

Sr26:

Sr26\#43 marker (Mago et al., 2005) was used to determine the Sr26 gene. This marker amplified DNA fragment of about 207bp .This fragment was absent in all the thirteen wheat cultivars (Fig.3). Dundas et al. (2007) stated that the effectiveness of this gene against the TTKS family of races, showed low frequency among modern cultivars, and its availability as donor lines with reduced alien segments makes Sr26 ideal for use by breeding programs. Bariana et al. (2007) reported that until now, Sr26 has been utilized as a source of resistance only in Australia. Liu et al. (2010) used PCR with marker Sr26\#43 and 6A-specific marker BE518379 as a codominant marker for $\mathrm{Sr} 26$. The previously published dominant markers $\mathrm{Gb}$ for $\mathrm{Sr} 25$ and Sr26\#43 for Sr26 were validated with eight wheat lines with or without Sr25 or Sr26. Sixin et al. (2010) stated that the co-dominant markers for $\mathrm{Sr} 25$ and $\mathrm{Sr} 26$ were validated with 37 lines with known stem rust resistance genes. A diverse set of 


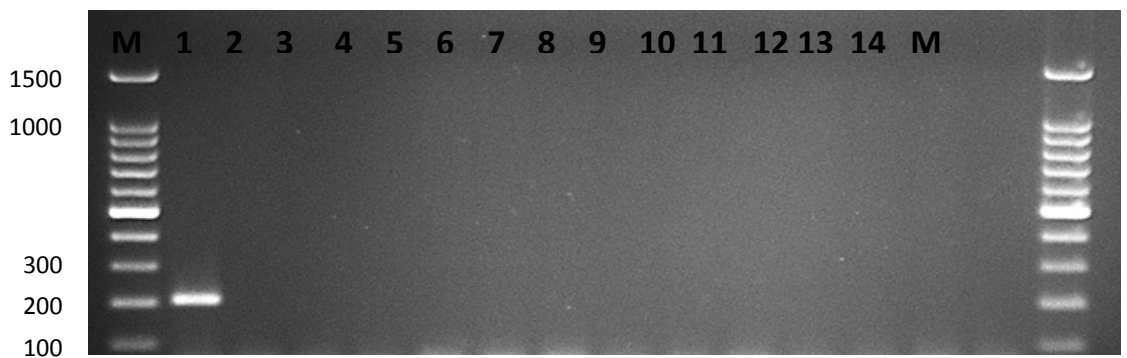

Fig. 3. The fragment profile of the $S r 26 \# 43$ with one band labeled as $207 \mathrm{bp}$ indicates that $\mathrm{Sr} 26$ was absent in all the thirteen bread wheat cultivars. M: 1000bp DNA ladder RTU (Gene Direx).1: Sr26 gene; 2: Gemmeiza-7, 3: Gemmeiza-10, 4: Gemmeiza-11, 5: Gemmeiza-12, 6: sids-12, 7: Sids-13, 8: Sids-14, 9: Giza-168, 10: Giza-171, 11: Misr-1, 12: Misr-2, 13: Sahka93, 14: Gemmeiza-9.

germplasm consisting 170 lines from CIMMYT, China, USA and other countries were screened with the co-dominant markers for $\mathrm{Sr} 25$ and Sr26. Five lines with the diagnostic fragment for Sr25 were identified. None of the 170 lines tested had Sr26, as expected.

Sr31:

IAG95-STS marker specific to Sr31 (Mago et al., 2002) amplified a DNA fragment of about $1100 \mathrm{bp}$. This fragment was present in six wheat cultivars only Gemmeiza-7, Gemmeiza-10, Gemmeiza-11, Gemmeiza-12, Sids-13 and Gemmeiza-9 (Fig.4). Since 1980s, wheat cultivars with Sr31 were widely grown in nearly everywhere major wheat-producing region throughout the world. Wanyera et al. (2006) reported that during 2003 and 2004, a majority of current Kenyan cultivars and a large portion of CIMMYT wheat germplasm with gene Sr31 planted in Kenya were susceptible to stem rust. Recently, the resistance of $\mathrm{Sr} 31$ was finally overcome, which isolates of Puccinia graminis f.sp. tritici with high virulence to Sr31 were detected including Ug99 race in Uganda in 1999 and pose a worldwide threat to wheat production in areas where Sr31 resistance is important (Pretorius et al., 2000).

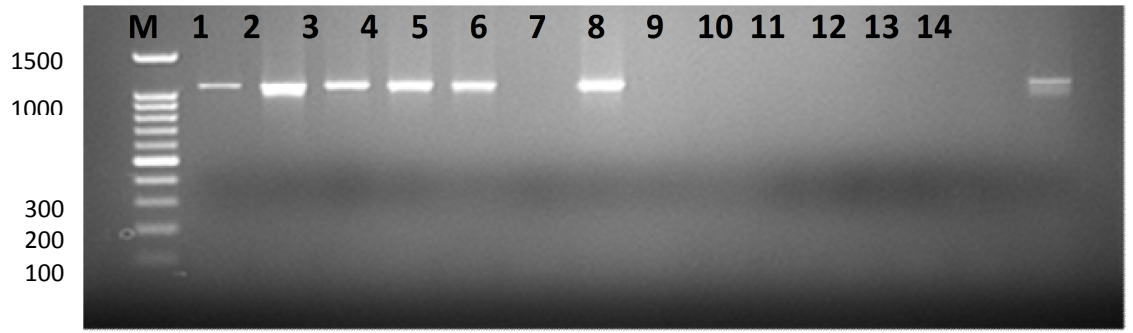

Fig.4. The fragment profile of the IAG95-STS with one band labeled as $1000 \mathrm{bp}$ indicates the presence of $\mathrm{Sr} 31$ in all the thirteen bread wheat cultivars. M: 100bp DNA ladder RTU (Gene Direx); 1: Sr31 gene; 2: Gemmeiza-7, 3: Gemmeiza-10, 4: Gemmeiza-11, 5: Gemmeiza-12, 6: sids-12, 7: Sids-13, 8: Sids-14, 9: Giza-168, 10: Giza-171, 11: Misr-1, 12: Misr-2, 13: Sahka93, 14: Gemmeiza-9. 
Similar results were obtained by EJaz et al. (2012) who screened 117 Pakistani wheat varieties with 18 DNA markers to detect the presence of stem rust resistance genes Sr2, Sr6, Sr22, Sr24, Sr25, Sr26, Sr31, and Sr38. Stem rust resistance genes $\mathrm{Sr} 22, \mathrm{Sr} 24, \mathrm{Sr} 25$, and Sr26 were absent from all varieties, whereas Sr2, Sr6, Sr31, and $\mathrm{Sr} 38$ were present at various frequencies.

The detected $\mathrm{Sr}$ genes and their frequencies in the 13 bread wheat cultivars could be summarized in Table (4). Sr 13 gene was the most frequency one (100\%) followed by $\operatorname{Sr} 25(84.61 \%)$, then $\operatorname{Sr} 31$ (46.15\%).However, the $\operatorname{Sr} 26$ gene was absent in all of them $(0 \%)$. Similar results were proposed by Purnhauser and Bóna (2009) who stated that among156 Hungarian wheat's, a significant part $(32.7 \%)$ had the 1RS.1BL wheat-rye chromosome translocation, the source of Sr31 gene. Also, EJaz et al. (2012) stated that in 117 Pakistani wheat varieties, the highest frequency was observed for $\operatorname{Sr} 2$ (9-79\% by different markers), followed by $\operatorname{Sr} 31$ (35\%), Sr6 (11\%), and $\operatorname{Sr} 38(9 \%)$. They reported that these results indicated that Pakistani varieties are being protected by very few resistance genes and lack resistance genes potentially effective against new stem rust races.

Table 4. Percentage frequency of the four monogenic stem rust genes, $\mathrm{Sr}$ 13, $\mathrm{Sr} 25, \mathrm{Sr} 26$ and $\mathrm{Sr} 31$ in thirteen bread wheat cultivars

\begin{tabular}{|l|c|c|c|c|}
\hline \multicolumn{1}{|c|}{ Sr gene Cultivar } & Sr13 & Sr25 & Sr26 & Sr31 \\
\hline Gemmeiza-7 & + & + & - & + \\
\hline Gemmeiza-10 & + & + & - & + \\
\hline Gemmeiza-11 & + & + & - & + \\
\hline Gemmeiza-12 & + & + & - & + \\
\hline Sids-12 & + & + & - & - \\
\hline Sids-13 & + & + & - & + \\
\hline Sids-14 & + & + & - & - \\
\hline Giza-168 & + & + & - & - \\
\hline Giza-171 & + & + & - & - \\
\hline Misr-1 & + & - & - & - \\
\hline Misr-2 & + & - & - & - \\
\hline Sahk93 & + & + & - & + \\
\hline Gemmeiza-9 & + & + & - & 46.15 \\
\hline Frequency $(\%)$ & $100 \%$ & 84.61 & 0.00 & - \\
\hline
\end{tabular}

Owing to the susceptible responses of the Egyptian bread wheat cultivars to Ug99 race and its variants under hot-spots of stem rust (Kenya, Ethiopia and Uganda) and to the local races. The understanding of the effectiveness of individual $\mathrm{Sr}$ genes against stem rust pathotypes will facilitate the utilization of these genes in breeding for stem rust resistance in wheat. More studies are needed to identify more resistance $\mathrm{Sr}$ genes and pyramiding these genes into our adapted germplasms. 


\section{R e f e r e n c e s}

Bariana, H.S.; Brown, G.N.; Bansal, U.K.; Miah, H.; Standen, G.E. and Lu, M. 200. Breeding triple rust resistant wheat cultivars for Australia using conventional and marker-assisted selection technologies. Australian J. Agric. Res., 58: 576-587.

Dundas, I.S.; Anugrahwati, D.R.; Verlin, D.C.; Park, R.F.; Bariana, H.S.; Mago, R. and Islam, A.K.M.R. 2007. New sources of rust resistance from alien species: meliorating linked defects and discovery. Australian J. Agric. Res., 58: 545-549.

Ejaz, M.; Iqbal, M.; Shahzad, A.; Ur-Rehman, A.; Ahmed, I. and Ali, G.A. 2012. Genetic variation for markers linked to stem rust resistance genes in Pakistani wheat varieties. Crop Sci. Soc. of America, 52: 2638-2648.

Friebe, B.; mJiang, J.; Knott, D.R. and Gill, B.S. 1994. Compensation indexes of radiation-induced wheat Agropyron elongatun translocations conferring resistance to leaf rust and stem rust. Crop Sci., 34: 400-404.

Ghazvini, H.; Colin, W.H.; Julian, B. and Thomas, F. 2013. Development of a multiple bulked segregant analysis (MBSA) method used to locate a new stem rust resistance gene (Sr54) in the winter wheat cultivar Norin 40. Theoretical and Applied Genetics, 126: 443-449.

Jin, Y.; Pretorius, Z.A.; Singh, R.P. and Fetch, J.R.T. 2008. Detection of virulence to resistance gene $\mathrm{Sr} 24$ within race TTKS of Puccinia graminis f.sp. tritici. Plant Dis., 92: 923-926.

Jin, Y.; Singh, R.P.; Ward, R.W.; Wanyera, R.; Kinyua, M.; Njau, P. and Pretorius, Z.A. 2007. Characterization of seedling infection types and adult plant infection responses of monogenic $\mathrm{Sr}$ gene lines to race TTKS of Puccinia graminis f.sp. tritici. Plant Dis., 91: 1096-1099.

Klindworth, D.L.; Miller, J.D.; Jin, Y. and Xu, S.S. 2007. Chromosomal locations of genes for stem rust resistance in monogenic lines derived from tetraploid wheat accession ST464. Crop Sci., 47:1441-1450.

Knott, D.R. 1962. The inheritance of resistance to races 15B and 56 of stem rust in the wheat variety Khapstein. Canad. J. Plant Sci., 42: 415-419.

Liu, S.; Yu, L.; Singh, R.P.; Jin, Y.; Sorrells, M.E. and Anderson, J. A. 2010. Diagnostic and co-dominant PCR markers for wheat stem rust resistance genes Sr25 and Sr26.Theoretical and Applied Genetics, 120: 691-697.

Mago, R.; Bariana, I.S.; Dundas, W.; Spielmeyer, G.J.; Lawrence, A.J.; pryor, A. and Ellis, G. 2005. Development of PCR markers for the selection of wheat stem rust resistance genes $\mathrm{Sr} 24$ and $\mathrm{Sr} 26$ in diverse wheat germplasm. Theoretical and Applied Genetics, 111: 496 - 504.

Mago, R.; Spielmeyer, W.; Lawrence, G.J.; Lagudah, E.S.; Ellis, J.G. and Pryor, A. 2002. Identification and mapping of molecular markers linked to rust resistance genes located on chromosome 1RS of rye using wheat-rye translocation lines. Theoretical and Applied Genetics, 104:1317-1324. 
McIntosh, R.; Dubcovsky, J.; Rogers, J.; Morris, C.; Appels, R. and Xia, X. 2011. Catalogue of gene symbols for wheat: Supplement Annu. Wheat News, 56: $273-282$.

Peterson, R.F.; Campbell, A.B. and Hannah, A.E. 1948. A diagnostic scale for estimating rust intensity of leaves and stem of cereals. Can. J. Res. Sect., 26: 496-500.

Pretorius, Z.A.; Singh, R.P.; Wagoire, W.W. and Payne, T.S. 2000. Detection of virulence to wheat stem rust resistance gene Sr31 in Puccinia graminis f.sp. tritici in Uganda. Plant Dis., 84: 203.

Purnhauser, L. and Bóna, L. 2009. Detection of Sr31 and Sr36 stem rust resistance genes by molecular markers in wheat cultivars registered in Hungary. Res. J. Agric. Sci., 41(2): 319-322.

Simons, K.; Abate, Z.; Chao, S.; Zhang, W.; Rouse, M.; Jin, Y.; Elias, E. and Dubcovsky, J. 2011. Genetic mapping of stem rust resistance gene $\operatorname{Sr} 13$ in tetraploid wheat (Triticum turgidum sp. durum L.). TAG Theoretical and Applied Genetics, 122: 649-658.

Singh, R.P.; Hodson, D.P.; Jin, Y.; Huerta-Espino, J.; Kinyua, M.G.; Wanyera, R.; Njau, P. and Ward, R.W. 2006. Current status, likely migration and strategies to mitigate the threat to wheat production from race Ug99 (TTKS) of stem rust pathogen. CAB Reviews: Perspective in Agriculture. Vet. Sci. Nat. Res., 54: 1-13.

Sixin, L.; Long-Xi, Y.U.; Singh, R.P.; Jin, Y.; Sorrells, M.E. and Anderson, J.A. 2010. Diagnostic and co-dominant PCR markers for wheat stem rust resistance genes Sr25 and Sr26. Theoretical and Applied Genetics, 120(4): 691-697.

Wanyera, R.; Kinyua, M.G.; Jin, Y. and Singh, R.P. 2006. The spread of stem rust caused by Puccinia graminis f.sp. tritici, with virulence on $S r 31$ in wheat in Eastern Africa. Plant Dis., 90: 113.

Zhang W. and Dubcovsky J. 2008. Association between allelic variation at the Phytoene synthase 1 gene and yellow pigment content in the wheat grain. Theoretical and Applied Genetics, 116: 635-645.

(Received 20/04/2014;

in revised form 25/05/2014) 


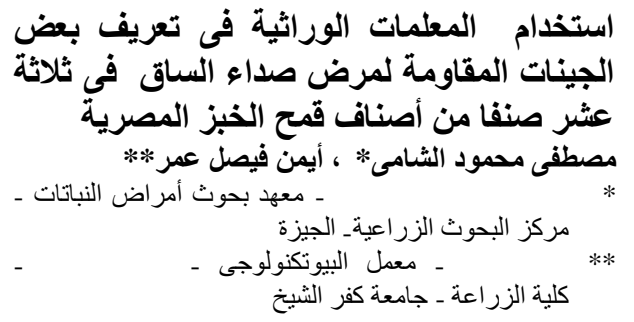

يعتبر مرض صدأ الساق فى القمح والذى يسببة الفطر بكسينيا جرامينيز

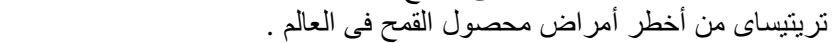

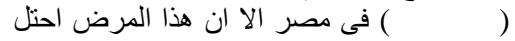

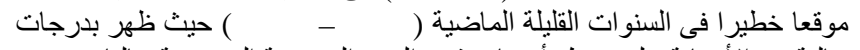

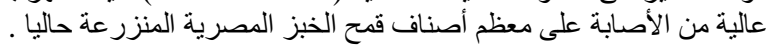

تم تقييم ثلاثون سلالة من سلالات القمح أحادية الجين المقاومة لمرض صدأ

سلالات اضافية تحت ظروف العدوى الطبيعية بمزر عة محطة البحوث الزر اعية

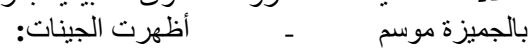

Sr 5 , Sr 9g, Sr 11, Sr 13, Sr 14, Sr 21,Sr22, Sr 24, Sr 28,

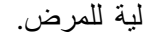
Sr36, and $\operatorname{Sr} 38$ لـ ( ) ( ) المتخصصة فى تعريف الجينات

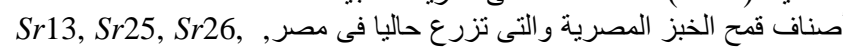

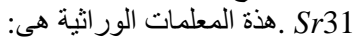

XBE403950EST- PSY-DI - Sr26\#43 - IAG95-STS

ولقد أظهرت النتائج أن الجين أس أر موجود فى جميع الأصناف المصرية

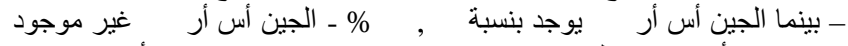

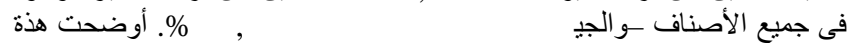

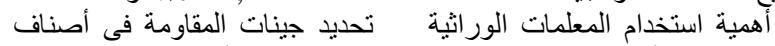

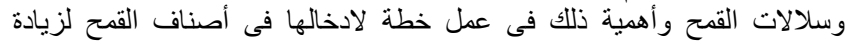

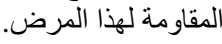

